\title{
Innovative processing for improved electrical steel properties ${ }^{(\bullet)}$
}

\author{
K. Verbeken*, I. Infante-Danzo*, J. Barros-Lorenzo*, J. Schneider* and Y. Houbaert*
}

\begin{abstract}
Electrical steel grades are the normal construction material for electrical motors and transformers because of their enhanced soft magnetic properties. One of the current trends in their production aims for increasing the silicon and/or aluminum concentration (above $3 \mathrm{wt} \%$ ) to reduce magnetic losses through increased electrical resistivity. This is very difficult to realize by conventional processing, mainly because of cracking during cold rolling. An alternative production route is proposed that raises the silicon and/or aluminum concentration by surface deposition of silicon and/or aluminum on a low-Si/low-Al steel substrate, e.g. by a short immersion in a molten $\mathrm{Al}-\mathrm{Si}$ bath, followed by its diffusion into the bulk during subsequent annealing. This diffusion substantially modifies the microstructural features and therefore affects the mechanical and magnetic properties. Results of research efforts to optimize this production route and to understand the mechanisms and effects of the structural changes are presented and discussed.
\end{abstract}

Keywords Electrical steel; Hot dipping; Diffusion annealing; Magnetic properties; Crystallographic texture.

\section{Innovación del proceso para mejorar las propiedades de los aceros eléctricos}

\begin{abstract}
Resumen
Los aceros eléctricos se usan, normalmente, en la construcción de motores eléctricos y transformadores debido a sus suaves propiedades magnéticas. Una de las tendencias actuales es producir aceros con contenidos mayores de silicio y/o aluminio (por encima de un $3 \%$, en peso) para reducir las pérdidas magnéticas a través del incremento de la resistividad eléctrica. Una de las desventajas de producir este tipo de aceros con altos contenidos de silicio y/o aluminio es el agrietamiento producido en el material durante el proceso de laminado en frío. Para incrementar el contenido de silicio y/o aluminio en aceros con bajos contenidos de estos elementos de aleación, se sugiere un procedimiento alternativo de producción que se basa, fundamentalmente, en depositar un recubrimiento rico en silicio y/o aluminio, en la superficie del acero. Por ejemplo, uno de los métodos utilizados es sumergir el material en una aleación liquida de Al-Si, seguido de un recocido para promover la difusión del aluminio y el silicio del recubrimiento al acero. Este proceso de difusión modifica, sustancialmente, la microestructura y, a su vez, deteriora las propiedades magnéticas y mecánicas. Algunos de los resultados obtenidos como parte del esfuerzo para optimizar este nuevo método de producción y sus efectos en los posibles cambios de la microestructura y propiedades, se presentan y analizan en este trabajo.
\end{abstract}

Palabras clave

\section{INTRODUCTION}

\subsection{Electrical steel}

The name "electrical steel" refers to special steel grades, which have excellent soft magnetic properties (such as magnetization behavior, permeability, coercive field and specific magnetic losses). They are the normal construction material for electrical motors and transformers. Basically, these steels are Fe-Si and $\mathrm{Fe}-\mathrm{Si}-\mathrm{Al}$ alloys and they are sold as plate material with a thickness of less than $1 \mathrm{~mm}$; usually values in the range 0.5 to $0.35 \mathrm{~mm}$.

One of the trends in their production seeks for an increase of the concentration of silicon and/or aluminum to values above $3 \mathrm{wt} \%$. This interest results from the fact that these alloys exhibit lower values of the magnetostriction $\lambda$ and of the magnetocrystalline anisotropy $\mathrm{K}$. In addition, they exhibit higher values of the electrical resistivity, which reduces the eddy current losses. Therefore, there has been a lot of interest, recently, trying to produce steel with an increased concentration of

(•) Trabajo recibido el día 11 de febrero de 2010 y aceptado en su forma final el día 12 de abril de 2010.

* Department of Materials Science and Engineering, Ghent University, Technologiepark 903 - B-9052 Gent-Zwijnaarde, Belgium e-mail: Kim.Verbeken@ugent.be, Yvan.Houbaert@ugent.be 
silicon and/or aluminum. This is difficult to realize during the conventional production process, mainly because of cracking during cold rolling, which is due to the appearance of the brittle ordered phases $\alpha_{1}$ or $\mathrm{DO}_{3}$ and $\alpha_{2}$ or $\mathrm{B}_{2}$, as can be seen in the phase diagram of figure $1^{[1]}$. In this work, results on an innovative processing route for the production of electrical steels with increased $(\mathrm{Si}, \mathrm{Al})$ content by hot dipping and diffusion annealing are discussed in detail.

\subsection{Microstructure of electrical steel}

As is well known, the magnetic properties of soft magnetic materials, such as electrical steel grades, are related to the microstructure and texture of the steel. The microstructural parameters that have a strong influence on the magnetic properties, such as magnetization curves, permeability, coercive field and specific magnetic losses, are mainly: grain size, inclusions and internal stresses, in relation with the value of the magnetostriction and surface defects. These microstructural parameters determine the domain wall pinning, that means the coercive force of the material, and the domain wall motion, which are both responsible for the magnetizing behavior at low and medium values of the applied external magnetic field and the hysteresis losses.
Crystallographic texture is important because the magnetization behavior of the bcc lattice of iron is different along the different crystallographic directions: $<100>$ directions are much more easily magnetized than $<110\rangle$ or $<111>$ directions, as is illustrated in figure 2 . The existing magnetic texture in polycrystalline materials determines the remanent magnetic induction and the domain rotation processes at high values of the applied external magnetic field. Consequently, the optimal texture for electrical steel used in rotating machines is the cube fibre texture in which the majority of the grains have a $<100>$ direction normal to the sheet plane. When an equal distribution of crystallographic orientations along this fibre is attained, this will offer the maximum permeability and isotropic magnetic properties in the sheet plane. This type of electrical steels and are called "non oriented" electrical steels. In applications for static electrical machines, such as transformers, a pronounced Goss texture $\{110\}<001>$ may be preferred, because the magnetic field can be aligned with the $<001>$ direction $^{[2]}$. These steels are the grain oriented electrical steel grades. The evaluation of the texture effect on the magnetic properties remains a challenge because it is very difficult to separate its effect from the one exerted by the grain size or second phase inclusions. Below some more detail on this will be given.

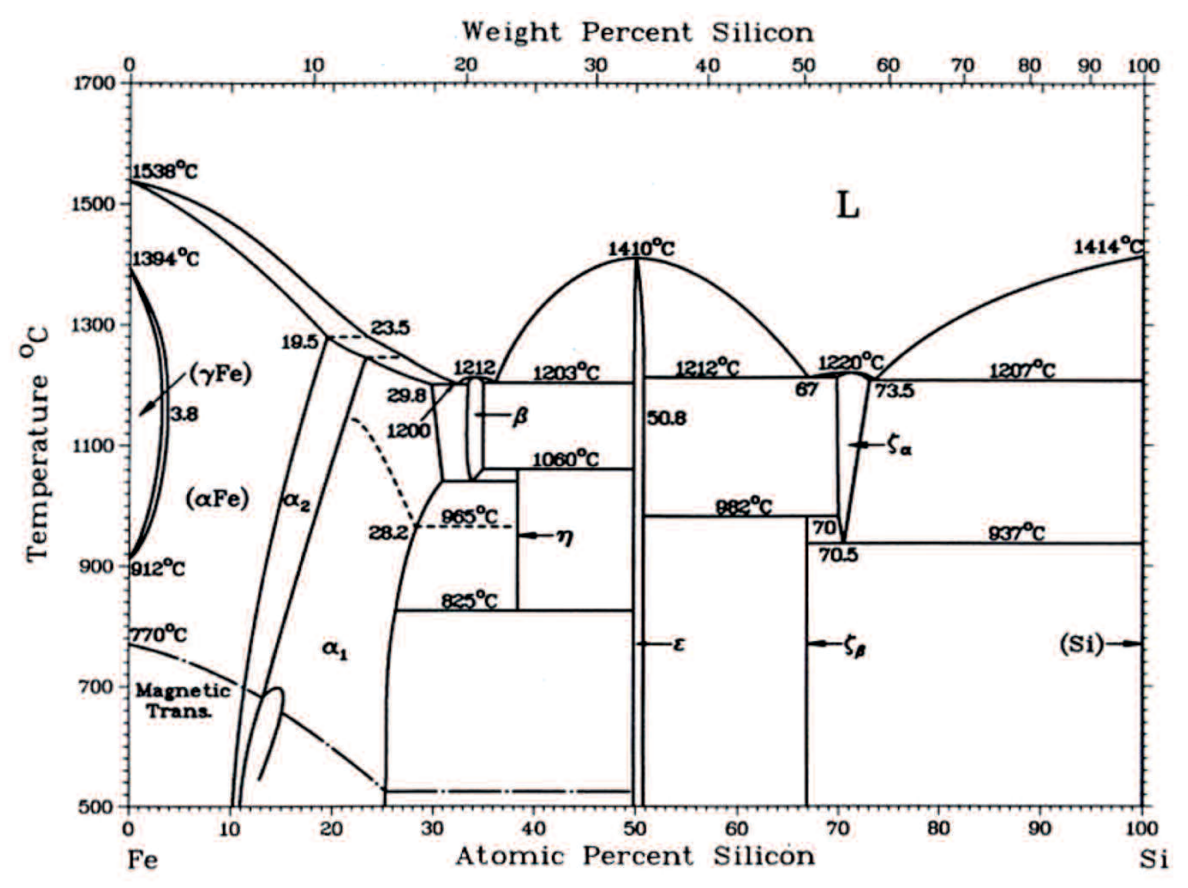

Figure 1. Fe-Si binary phase diagram.

Figura 1. Diagrama de fase binario Fe-Si. 

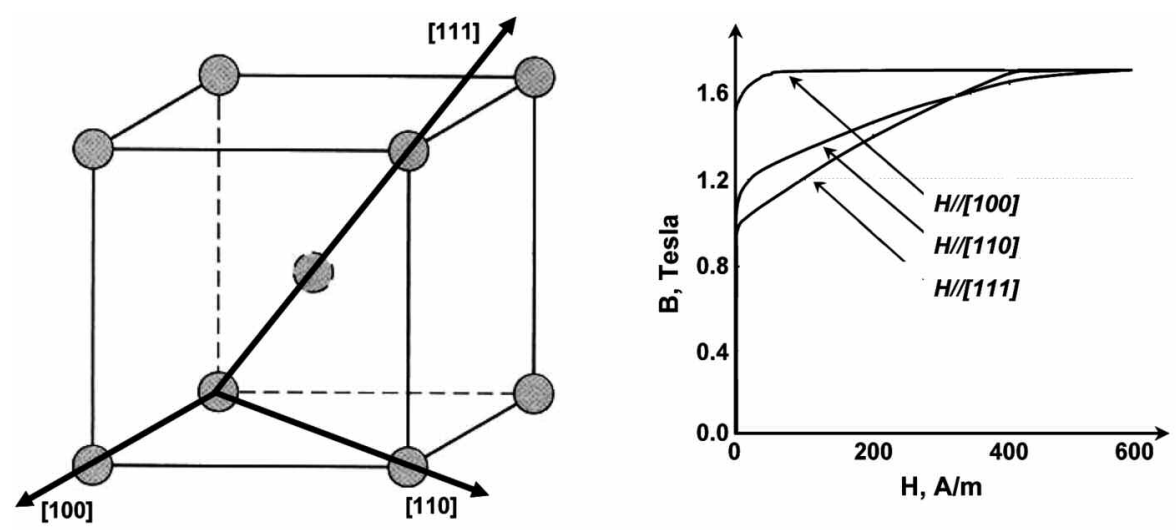

Figure 2. Magnetization curves for a single crystal of bcc iron as a function of the crystallographic direction.

Figura 2. Curvas de magnetización para un solo cristal de hierro bcc en función de la dirección cristalográfica.

\section{PROCESSING ROUTE}

\subsection{Basic principles}

It is not possible to produce thin strip of FeSi alloys with a high silicon content following the conventional processing route and obtain an appropriate steel quality. Using a modified hot- and cold rolling practice, according to the metallurgical processing route described in ${ }^{[3]}$, taking into account time and temperature dependent local ordering, plates or strips without cracks can be produced. Another procedure to overcome the cracking problem is a diffusion technique to enrich conventional steel $(\mathrm{Si}<3.2 \mathrm{wt} \%)$ up to $6.5 \mathrm{wt} \%$ Si using silicon from an applied coating. Nowadays, chemical vapor deposition (CVD) of silicon followed by diffusion annealing is already used industrially ${ }^{[4]}$. Other alternatives were studied by He et al..$^{[5]}$ and by Dong et al. ${ }^{[6]}$, who used physical vapor deposition and pulsed Nd:YAG laser cladding, respectively. A concentration increase of silicon and/or aluminum obtained by surface deposition of silicon and/or aluminum by a short hot dipping in a molten hypo- or hypereutectic Al-Si bath, followed by a diffusion annealing has been discussed in $^{[7}$ and 8$]$. By doing so, homogeneous or inhomogeneous distributions of $(\mathrm{Si}, \mathrm{Al})$ across the width of the strips can be obtained, as will be illustrated further on in this work, which is also the case for the CVD- followed by diffusion annealing, as reported by Okada et al. ${ }^{[4]}$.

When conventional electrical steel with a silicon content lower than approximately $2.0 \mathrm{wt} \%$ is used as a substrate, the steel presents the usual ferrite to austenite phase transformation, whereas a steel substrate with a silicon content above $2.0 \mathrm{wt} \%$ does not form any Á phase; the material remains ferritic. In the present work, most reported results are on a $\mathrm{Fe}(\mathrm{Si}-\mathrm{Al})$ steel substrate without phase transformation. This type of material was chosen because of the high level of alloying elements (mainly Si and Al) already present and because of their higher diffusivity in ferrite compared to austenite. Nevertheless, it will be demonstrated that the immersion and diffusion technique may be applied to substrates with low, medium and high $(\mathrm{Si}, \mathrm{Al})$ content, to obtain materials with higher ( $\mathrm{Si}, \mathrm{Al}$ ) content and homogeneous or inhomogeneous distributions of $(\mathrm{Si}, \mathrm{Al})$ across the width.

Fully processed electrical steels as well as hot rolled materials, especially with low thickness, or cold rolled materials may be used as substrates. Cold rolling of the material after dipping and before the annealing treatment to get the desired final thickness, especially as thin electrical steel with a thickness smaller than $0.35 \mathrm{~mm}$, appears to be an interesting variant in the production route, called intermediate cold rolling (ICR) ${ }^{[9]}$. Figure 3 gives a schematic overview of one of the possible processing routes.

\subsection{Fabrication technique}

The immersion was performed in equipment originally designed for hot dip galvanizing, i.e. a Rhesca ${ }^{\circledR}$ hot dip simulator as illustrated in figure 4. This simulator is composed of two chambers separated by a gate valve, which only opens when 
INNOVATIVE PROCESSING FOR IMPROVED ELECTRICAL STEEL PROPERTIES INNOVACIÓN DEL PROCESO PARA MEJORAR LAS PROPIEDADES DE LOS ACEROS ELÉCTRICOS

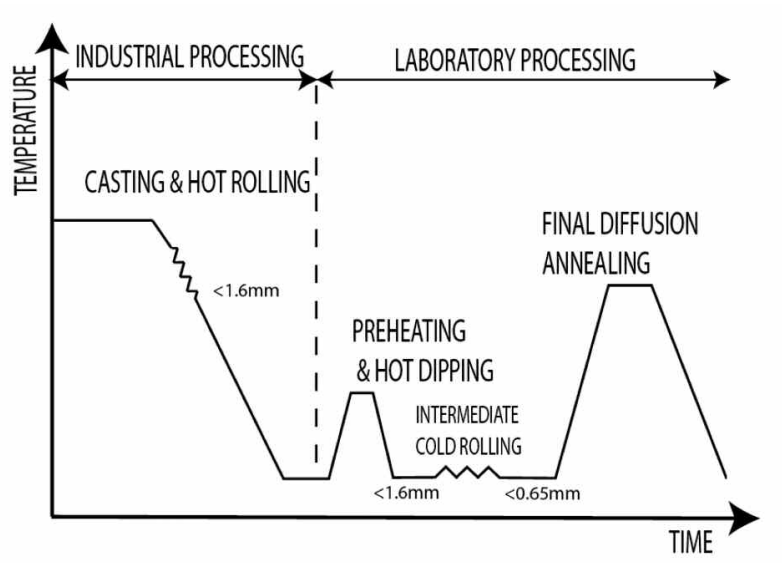

Figure 3. Overview of the complete experimental set-up, including industrial processing, followed by the processing according to present method, with intermediate cold rolling (ICR).

Figura 3. Visión general del montaje completo, abarcando el proceso industrial seguido del proceso de acuerdo al presente método y, con laminado en frío intermedio ( $L F I)$.

the sample is driven into the bath. The lower chamber contains a resistance furnace in which a graphite-SiC crucible is placed with the molten AlSi alloy. Both hypo- and hypereutectic alloys were used: in the first case, the aim was to deposit an aluminum rich coating on the substrate, in the second case, a silicon rich coating ${ }^{[7}$ and 8$]$. Bath temperature is chosen as a function of its composition. Because the steel substrate partially dissolves in the molten bath, experiments were performed with unsaturated and with iron saturated baths. The lower chamber is kept under a flux of $\mathrm{N}_{2}$ to prevent oxidation of the melt.

Before the immersion tests, cold rolling was used to obtain the desired final thickness. The steel plates were cleaned with $\mathrm{CCl}_{4}$ for degreasing and rinsed with acetone. Series of different alloys were used for the dipping experiments. The sample is positioned in the upper chamber (1) and then the chamber is evacuated to $10^{-2} \mathrm{~Pa}$ and refilled with a $\mathrm{N}_{2}+5 \% \mathrm{H}_{2}$ gas mixture (reducing atmosphere to avoid and/or eliminate oxidation). The sample is preheated in the IR furnace (2) (typically $850^{\circ} \mathrm{C}$ for $45 \mathrm{~s}$ ). After the preheating, the sample is driven at $750 \mathrm{~mm} / \mathrm{s}$ into the molten bath (4) where it stays between 0.1 and $200 \mathrm{~s}$. In the final step, the sample is cooled slowly in the IR furnace (annealing for $30 \mathrm{~s}$ at $800^{\circ} \mathrm{C}$ and then cooled at $\left.30^{\circ} \mathrm{C} / \mathrm{min}\right)$ or fast $\left(450^{\circ} \mathrm{C} / \mathrm{min}\right)$ in the cooling system (1) with a $\mathrm{N}_{2}$ flow of $100 \mathrm{l} / \mathrm{min}$ at the top of the upper chamber.
(5)
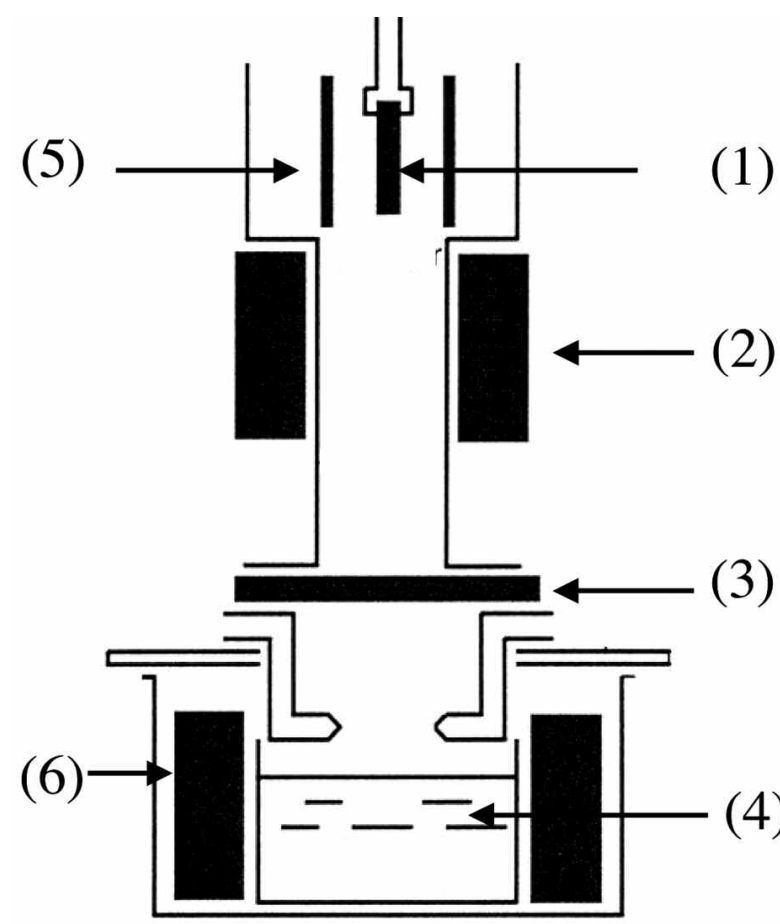

Figure 4. Schematic diagram of the hot dip simulator: (1) sample, (2) IR (infrared) furnace, (3) gate valve, (4) Al-Si molten alloy, (5) cooling cystem, (6) resistance furnace.

Figura 4. Diagrama esquemático del simulador de inmersión en caliente: (1) muestra, (2) horno infrarrojo, (3) válvula de compuerta, (4) aleación líquida de Al-Si, (5) sistema de enfriamiento, (6) horno de resistencia.

The annealing is performed after immersion in a separate device. The samples are reduced in size by cutting and placed in a quartz tube with controlled atmosphere (vacuum) to avoid oxidation. The parameters of the diffusion annealing can be changed in a broad range, depending on the diffusing element ( $\mathrm{Si}$ or $\mathrm{Al}$ or both). The diffusion annealing was performed outside the hot dip simulator, under vacuum at temperatures between 850 and $1250^{\circ} \mathrm{C}$ using different holding times. Samples of $5 \mathrm{~mm}$ width and a minimum length of $30 \mathrm{~mm}$ were encapsulated in quartz tubes under vacuum and then diffusion annealed. Samples were heated to the annealing temperature in two different ways: a) at 8-10 ${ }^{\circ} \mathrm{C} / \mathrm{min}$ until the annealing temperature or $\mathrm{b}$ ) introducing the samples directly into the furnace at the aimed annealing temperature, in these cases the heating rate was fast (less than 5 min to heat up the sample completely). Diffusion times varied from 30 minutes to 3 hours. After annealing, the samples were air cooled to room temperature. 
After completing the processing, the samples are fully characterized, for microstructural properties (including crystallographic texture), chemical compositions (identification of possible concentration gradients), mechanical properties (important for the punching of the final material) and magnetic properties (electrical applications). More details on the mechanical and magnetic properties can be found elsewhere ${ }^{[10}$ and 11$]$. The Al-Si coated plates were cut normal to the solid/liquid interface and then mechanically polished (mirror finished). The samples were examined by scanning electron microscopy. Composition of the phases and concentration profiles were obtained by energy dispersive spectroscopy (EDS), information on the crystallographic texture was obtained by XRD (X-ray diffraction) and EBSD (electron backscatter diffraction). XRD was used to measure the texture by measuring pole figures and calculating orientation distribution functions. Pole figures were measured by the Schultz reflection method using an Euler cradle goniometer. Measurements were performed using a Siemens D5000 diffractometer with Mo radiation $\left(\lambda_{\mathrm{Mo}}=0.071 \mathrm{~nm}\right)$ in the $2 \theta_{\mathrm{Mo}}$ range of $18-55^{\circ}$. EBSD measurements were carried out on a FEI XL30 ESEM equipped with $\mathrm{a} \mathrm{LaB}_{6}$-filament, using a TSL-OIM ${ }^{\circledR}$ attachment. Samples were prepared by standard metallographic procedures.

\subsection{Substrate selection}

In order to fully characterise the proposed processing route, a broad range of steel substrates has been used for the immersion and diffusion annealing tests. Most important parameter is the silicon content, which determines the occurrence of the ferrite to austenite phase transformation. Besides a ULC steel (ultra low carbon), industrial low silicon and high silicon electrical steels have been used. These steels have been industrially produced for electrical applications and should have a "clean" composition, with already acceptable magnetic properties as a soft magnetic material. These properties should be further improved by the innovative processing route described in this work. Chemical composition and thermomechanical treatment of a series of substrates used in this work are summarized in table I.

\section{MATERIAL CHARACTERIZATION}

\subsection{Hot dipping and surface layer characterization}

Samples were examined immediately after hot dipping, before the diffusion annealing, to study the interactions between molten bath and substrate. The chemical and physical interaction between substrates of $\mathrm{Fe}-\mathrm{Si}$ alloys in the range $0-3.8 \mathrm{wt} \% \mathrm{Si}$ and a molten $\mathrm{Al}+25 \mathrm{wt} \%$ silicon alloy at $800^{\circ} \mathrm{C}$ are considered here for different hot dipping reaction times (from 0.1 to $200 \mathrm{~s}$ ).

Several intermetallic phases have been identified, such as $\mathrm{Fe}_{2} \mathrm{Al}_{5}, \mathrm{~T}_{1}-\mathrm{Al}_{3} \mathrm{Fe}_{3} \mathrm{Si}_{2}, \mathrm{~T}_{2}-\mathrm{Al}_{12} \mathrm{Fe}_{6} \mathrm{Si}_{5}, \mathrm{~T}_{3}$ $\mathrm{Al}_{2} \mathrm{FeSi}$ and $\mathrm{T}_{4}-\mathrm{Al}_{3} \mathrm{FeSi}_{2}$, which were already reported in literature ${ }^{[12}$ and 13$]$ dealing with the interaction between iron and molten Al-Si alloys. In addition, an ordered phase $\mathrm{Fe}_{3} \mathrm{Si}\left(\mathrm{DO}_{3}\right)$ appears in contact with the Fe-Si substrate. Diffusion reaction and solidification phenomena appear to be involved in the development of the coating. The growth kinetics has been studied and diffusion appears as the growth controlling step for the intermetallic compounds. Special attention was paid to the effect

Table I. Chemical composition (wt \%) and thermo-mechanical processing of different substrates

Tabla I. Composición química (\% en peso) y tratamiento termo-mecánico de los diferentes materiales

\begin{tabular}{ccclccc}
\hline Alloy & Si & Al & Mn & P & Cold rolled Annealed \\
\hline A & $<0.005$ & 0.02 & 0.072 & 0.012 & yes & yes \\
B & 1.3 & 0.09 & 0.25 & 0.055 & yes & no \\
C & 1.9 & 0.005 & 0.049 & 0.008 & yes & no \\
D & 2.4 & 0.29 & 0.23 & 0.008 & yes & no \\
E & 2.4 & 0.020 & 0.12 & 0.012 & yes & no \\
F & 3.2 & 0.016 & 0.003 & 0.016 & yes & no \\
G & 3.7 & 0.007 & 0.036 & 0.008 & yes & no \\
\hline
\end{tabular}


INNOVATIVE PROCESSING FOR IMPROVED ELECTRICAL STEEL PROPERTIES INNOVACIÓN DEL PROCESO PARA MEJORAR LAS PROPIEDADES DE LOS ACEROS ELÉCTRICOS

of the microstructure of the dipped sheet on the interaction with the molten alloy. The higher deformed structures reacted faster; this effect can be explained by the faster diffusion through high diffusivity paths such as grain boundaries and dislocations.

For the first experiments, plates of the different alloys were dipped for different times and then the samples were fast or slowly cooled in the IR furnace. The phase layers formed on and inside the substrate differ as a function of the cooling rate after the dipping. On the one hand, fast cooled samples (Fig. 5, left) show a total coating thickness about $40-50 \mu \mathrm{m}$ and a very irregular interaction layer of about 10-20 $\mu \mathrm{m}$ composed of at least two different intermetallic layers: one very thin layer of 2 to $5 \mu \mathrm{m}$ in contact with the substrate and identified as $T_{1}-T_{9}$ and a second very irregular one, identified as $\mathrm{T}_{4}$, (for phase compositions, see table II). The outer layer contains pure silicon embedded in an eutectic Al-Si matrix, a $\mathrm{DO}_{3}$ layer can be present if the dipping times are long enough, i.e. at least $5 \mathrm{~s}$ and if the silicon content of the substrate is high enough, i.e. at least $2.4 \mathrm{Si}$ wt \%.

Slowly cooled samples, on the other hand, (Fig. 5, right) have the same coating thickness, but a different aspect. The very irregular shape of the intermetallic $\mathrm{T}_{4}$ phase smoothes and the pure silicon areas are not found anymore. $\mathrm{A} \mathrm{DO}_{3}$ layer appears at the interface substrate/coating even for the shortest dipping times. The intermetallic layer $T_{1}-T_{9}$ becomes more irregular and it is displaced by a new layer that appears to be $\eta$ $\mathrm{Fe}_{2} \mathrm{Al}_{5}$. A new intermetallic layer grows between $\mathrm{T}_{1}$ $T_{9}$ and $T_{4}$ whose composition corresponds to $T_{2}-T_{3}$.

\subsection{Interface phase morphology, growth of a $\mathrm{DO}_{3}$ layer during hot dipping}

Special attention needs to be given to a detailed study of the interface phase morphology during hot dipping, since the $\mathrm{Fe}_{3} \mathrm{Si}$ layer is difficult to distinguish in the SEM with the Secondary Electron (SE) detector. However, with the Backscattered Electron (BSE) detector, together with a careful etching with $5 \%$ $\mathrm{HF}$, followed by Nital etching, the $\mathrm{Fe}_{3} \mathrm{Si}$ interface and thin layers $\mathrm{Fe}_{2} \mathrm{Al}_{5}$ and $\mathrm{T}_{1}$ are clearly revealed.

The total coating thickness does not vary for the time range used in these experiments; values are between 40 and $60 \mu \mathrm{m}$, as can be observed in figure 5 . This is a very low thickness when compared with results for hot dipping in pure aluminum (typical thickness around $300 \mu \mathrm{m}$ ) and can be explained by the double effect of silicon in both the molten alloy and in the substrate; i.e. silicon present in the substrate reduces the activity coefficient of aluminum in iron, which also results in a lower thickness ${ }^{[14]}$. At the same time, silicon, even in small quantities, clearly modifies the coating composition and morphology although the mechanisms by which silicon influences coating formation and inhibits its growth are not yet clear. Nicholls ${ }^{[15]}$ and Heumann et al. ${ }^{[16]}$ suggested that silicon atoms occupy the structural vacancies present in the $\eta-\mathrm{Fe}_{2} \mathrm{Al}_{5}$ phase and therefore inhibit the growth of this phase and consequently of the coating. Other authors[17], claimed that silicon enhances the velocity of iron enrichment in the initially iron free melts. They concluded that silicon accelerates the iron dissolution and coating spalling and therefore the
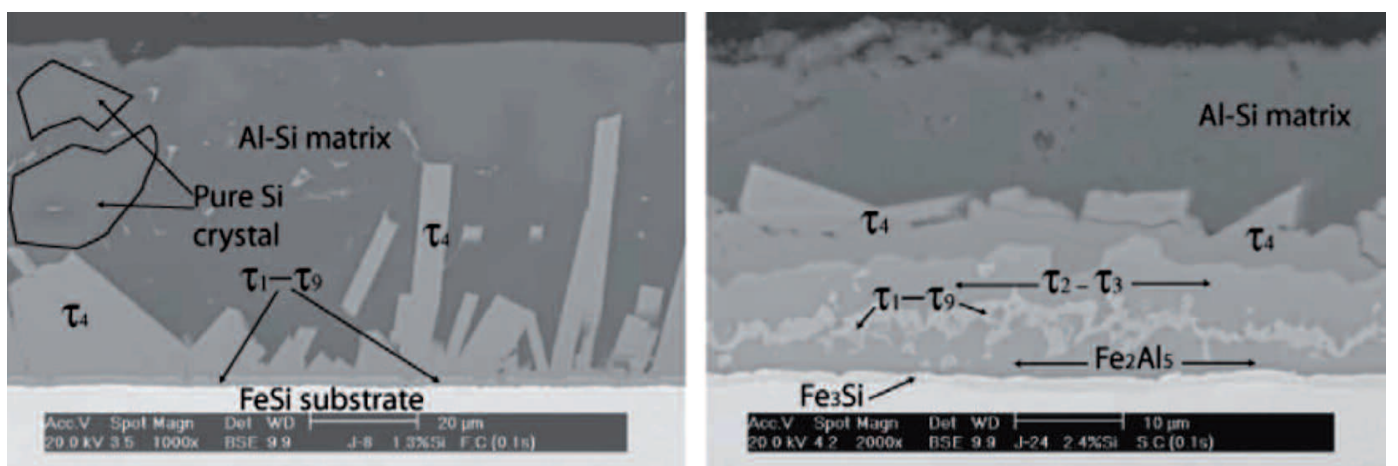

Figure 5. Coating layer after hot dipping: (left) a substrate with $1.3 \mathrm{wt} \% \mathrm{Si}$ and fast cooled after dipping ( $\mathrm{N}_{2}$-flow), (right) a substrate with $2.4 \mathrm{wt} \% \mathrm{Si}$ and slowly cooled in the IR furnace.

Figura 5. Capa de recubrimiento después de la inmersión en caliente: (izquierda) material con $1,3 \%$ en peso de Si enfriado rápidamente después de la inmersión (con un flujo de $N_{2}$ ), (derecha) material con $2,4 \%$ en peso de Si enfriado lentamente en el horno infrarrojo. 
Table II. Theoretical and measured composition of intermetallic compounds shown in figure 5

Tabla II. Composición teórica y medida de los intermetálicos mostrados en la figura 5

\begin{tabular}{cccccccc}
\hline & & \multicolumn{3}{c}{ Theoretical at \% } & \multicolumn{3}{c}{ Measured at \% } \\
\cline { 3 - 8 } Phase & Composition & $\mathbf{A l}$ & $\mathbf{F e}$ & $\mathbf{S i}$ & $\mathbf{A l}$ & $\mathbf{F e}$ & $\mathbf{S i}$ \\
\hline $\mathrm{T}_{1}$ & $\mathrm{Al}_{0.42} \mathrm{Fe}_{0.39} \mathrm{Si}_{0.19}$ & 42 & 39 & 19 & 39 & 34 & 27 \\
$\mathrm{~T}_{9}$ & $\mathrm{Al}_{0.36} \mathrm{Fe}_{0.36} \mathrm{Si}_{0.28}$ & 36 & 36 & 28 & 39 & 34 & 27 \\
$\mathrm{~T}_{2}$ & $\mathrm{Al}_{0.54} \mathrm{Fe}_{0.26} \mathrm{Si}_{0.20}$ & 54 & 26 & 20 & 52 & 24 & 23 \\
$\mathrm{~T}_{3}$ & $\mathrm{Al}_{0.50} \mathrm{Fe}_{0.25} \mathrm{Si}_{0.25}$ & 50 & 25 & 25 & 52 & 24 & 23 \\
$\mathrm{~T}_{4}$ & $\mathrm{Al}_{0.48} \mathrm{Fe}_{0.15} \mathrm{Si}_{0.37}$ & 48 & 15 & 37 & 50 & 17 & 33 \\
$\eta$ & $\mathrm{Fe}_{2} \mathrm{Al}_{5}$ & 71 & 29 & - & 69 & 31 & - \\
$\mathrm{DO}_{3}$ & $\mathrm{Fe}_{3} \mathrm{Si}$ & - & 75 & 25 & - & 77 & 23 \\
\hline
\end{tabular}

observed coating is thinner. On the other hand, Eggeler et al. ${ }^{[18]}$ demonstrated that for an $\mathrm{Al}-2 \% \mathrm{Si}$ melt, silicon is incorporated into the $\eta-\mathrm{Fe}_{2} \mathrm{Al}_{5}$ phase but the Fe dissolution was not accelerated in the silicon containing melt.

As can be seen in figure 6 , a characteristic layer exists between the substrate and the coating. The silicon concentration in this layer remains constant at 25 at $\%$, which corresponds to the ordered phase $\mathrm{Fe}_{3} \mathrm{Si}$. The growth of this interface layer is very rapid and depends on the silicon content of the substrate and on the dipping time; it appears in less than $100 \mathrm{~s}$ and its composition varies with the substrate composition. As can be seen in figure 7 , for the substrate composition ranging from 0 to almost $4 \mathrm{wt} \% \mathrm{Si}$, a $\mathrm{DO}_{3}$ type ordered structure is always formed, but the distribution between silicon and aluminum atoms in $\mathrm{DO}_{3}$ positions varies from $(0$ at $\% \mathrm{Si}+25$ at $\% \mathrm{Al})$ to $(25$ at $\% \mathrm{Si}+0$ at $\%$ $\mathrm{Al})$ with increasing silicon content. Nevertheless, in all cases the sum (at $\% \mathrm{Si}+$ at $\% \mathrm{Al})$ remains constant at 25 at \%.

On the one hand, this kind of growth of an ordered phase is reported in literature for the interaction between iron and pure silicon in diffusion couples, when studying the interaction of steel with $\mathrm{Mg}-\mathrm{Si}$ alloys at 950-1,000 $\mathrm{K}$ and during the reaction of iron and silicon carbide ${ }^{[19}$ and 20$]$. On the other hand, literature does mention $\mathrm{Fe}_{3} \mathrm{Si}$ growth when studying the interaction between iron and steel with Al-Si liquid alloys, but most of the studies concerning steel interaction with Al-Si are devoted to stainless steel and nickel containing steels ${ }^{[21}$ and 22].

The growth of an ordered $\mathrm{Fe}_{3} \mathrm{Si}\left(\mathrm{DO}_{3}\right)$ layer with a strong dependence on the silicon content of the

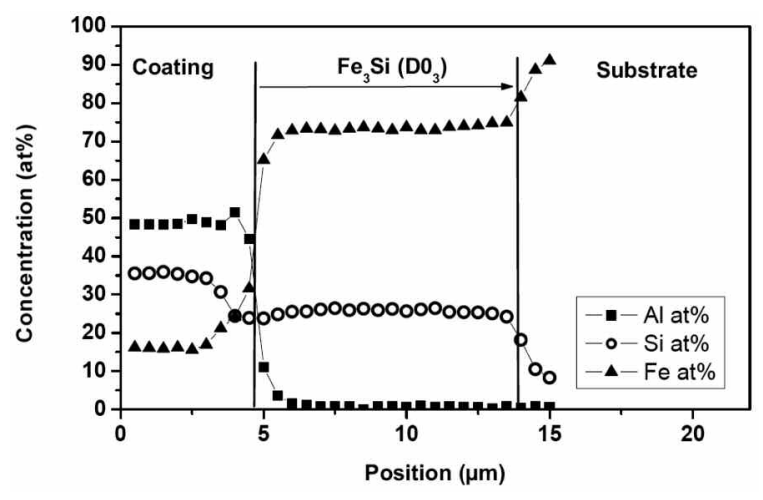

Figure 6. Composition profile across the coating thickness on a Fe substrate with $3.7 \mathrm{wt} \% \mathrm{Si}$, hot dipped for $100 \mathrm{~s}$ and fast cooled with a $\mathrm{N}_{2}$ flow.

Figura 6. Perfiles de concentración a lo largo del espesor del recubrimiento en un material de Fe con 3,7\% en peso de Si, inmerso en caliente durante 100 s y enfriado rápidamente con un flujo de $\mathrm{N}_{2}$.

substrate appears to be a main characteristic of the process developed here. Its growth obeys a parabolic law in the time range studied indicating that diffusion is the dominant step in the overall process of reactiondiffusion.

\subsection{Diffusion annealing}

The aim of the diffusion annealing is to enrich the substrate in silicon and aluminum by the diffusion of 
INNOVATIVE PROCESSING FOR IMPROVED ELECTRICAL STEEL PROPERTIES INNOVACIÓN DEL PROCESO PARA MEJORAR LAS PROPIEDADES DE LOS ACEROS ELÉCTRICOS

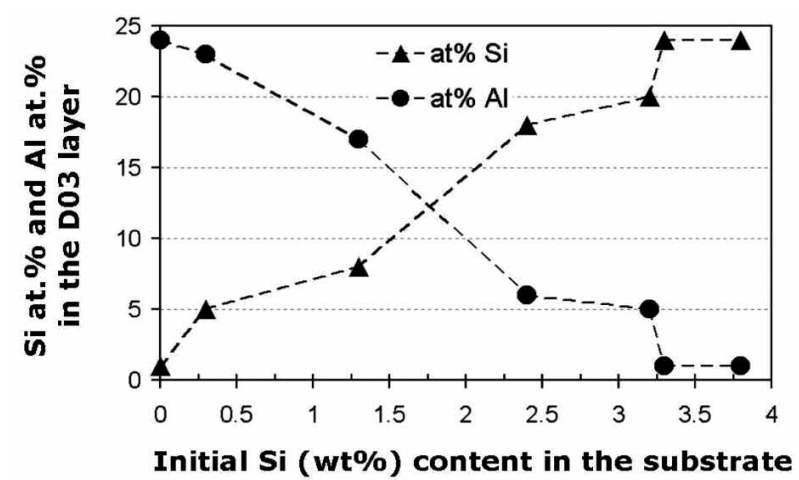

Figure 7. Change in composition of the ordered $\mathrm{DO}_{3}$ phase with increasing silicon content of the substrate.

Figura 7. Cambio en la composición de la fase ordenada $\mathrm{DO}_{3}$ con el incremento de la cantidad de silicio en el material.

these elements from the surface coating into the underlying material. The diffusion of silicon and aluminum in $\mathrm{Fe}$-Si alloys is, from a theoretical viewpoint, a difficult issue. In the first place, we deal with a ternary system which complicates the mathematical formulation of the diffusion equations. Secondly, the thermodynamics of the Fe-Si-Al system; $\mathrm{Fe}-\mathrm{Al}$ and $\mathrm{Fe}-\mathrm{Si}$ present a complicated phase diagram at the concentration and temperature range in which the diffusion process takes place since ferrite, austenite and the ordered phases $\mathrm{B}_{2}$ and $\mathrm{DO}_{3}$ are present. These ordered phases are also present in the ternary $\mathrm{Fe}-\mathrm{Si}$ - $\mathrm{Al}$ system and their effect on the diffusion is complicated. Further details can be found in ${ }^{[23]}$.

Figure 8 represents some typical concentration profiles for an original steel substrate with $3.2 \mathrm{wt} \%$ $\mathrm{Si}$ and $1.0 \mathrm{~mm}$ thickness. The sample was intermediate cold rolled (ICR, cf. Fig. 3) after dipping to a final thickness of $0.8,0.65$ and $0.5 \mathrm{~mm}$, respectively. Diffusion annealing was performed at $1,150{ }^{\circ} \mathrm{C}$ for $30 \mathrm{~min}$. In the case presented in figure 8 , the original silicon content of the substrate did not change notably, but alternatively, there was a clear increase of the aluminum content of the substrate, which originally did not contain any aluminum. In the outer layers of the material, the $\mathrm{Al}$ content was increased to a mean value of about $4 \mathrm{wt} \%$, over a depth of more than $100 \mu \mathrm{m}$ on both sides.

There is a fundamental interest in the understanding of the magnetic behavior of steel laminations with a concentration profile as shown in figure 8 . Therefore, the resulting magnetization behavior for samples with a large gradient of the $(\mathrm{Si}$, Al) content and those with a more smooth distribution across the thickness are compared.

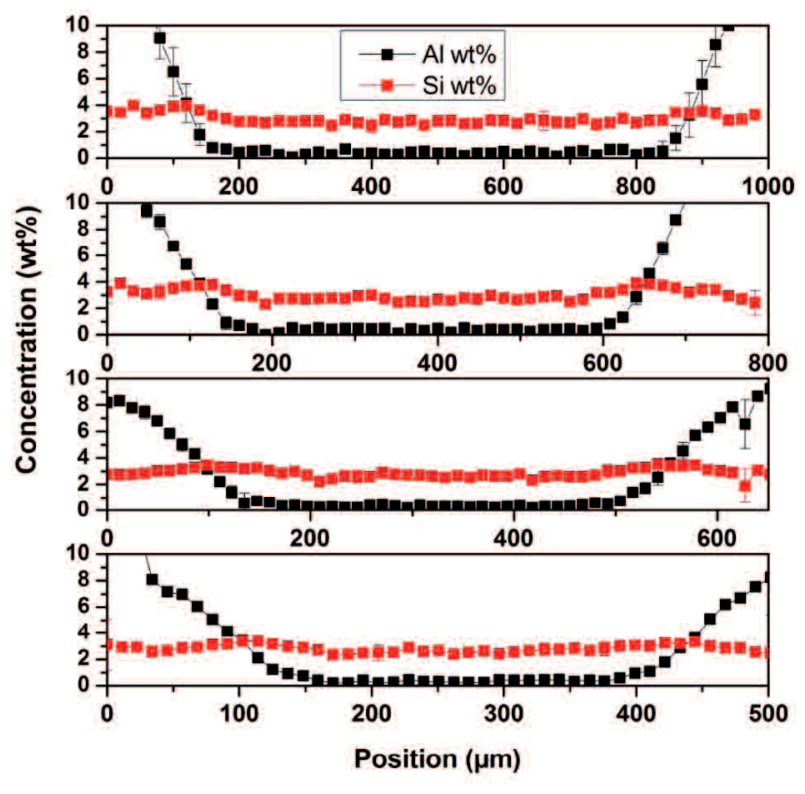

Figure 8. Examples of concentration profiles after diffusion annealing for $30 \mathrm{~min}$ at $1,150^{\circ} \mathrm{C}$.

Figura 8: Ejemplos de perfiles de concentración después del recocido de difusión durante $30 \mathrm{~min}$ a $1.150^{\circ} \mathrm{C}[5]$.

The results may indicate that the magnetization behavior of the dipped and diffusion annealed samples may be well understood on the basis of the known relations between the parameters for the magnetization behavior and the fundamental magnetic parameters $\mathrm{A}, \mathrm{K}$, as well as the structure sensitive properties $\mathrm{L}$ (domain spacing), $\mathrm{d}_{\mathrm{W}}$ (domain wall width). There appears to be almost no difference in the behavior of samples with homogeneous or inhomogeneous $(\mathrm{Si}, \mathrm{Al})$ distributions across the strip thickness. The frequency dependence of the relevant magnetic parameters coercive force and permeability is also nearly the same. The spatial fluctuations of the $(\mathrm{Si}, \mathrm{Al})$ content seem to be less relevant for the magnetization behavior. There is no indication that the material with a large gradient in the $(\mathrm{Si}, \mathrm{Al})$ content across the thickness has to be described by a superposition of two materials. More details were given elsewhere ${ }^{[24]}$.

\subsection{Modeling the diffusion process}

The industrial production of the alloys described here requires models for predicting the concentration profile of $(\mathrm{Si}, \mathrm{Al})$ resulting from the diffusion process and the changes of the mechanical and magnetic properties associated with the resulting concentration profiles of $(\mathrm{Si}, \mathrm{Al})$. 
The diffusion process has been studied using commercial software such as DICTRA ${ }^{\circledR}$ and Thermocalc ${ }^{\circledR}$ for the modeling of diffusion controlled transformations. Experimental validation was made on some base alloys and results for the 3 wt \% Si material are reported here. Substrates were coated by dipping in a molten $\mathrm{Al}-25 \mathrm{Si}$ wt \% alloy, followed by annealing at different temperatures and times. The results show that silicon concentration profiles can be accurately predicted. However, when considering both silicon and $\mathrm{Al}$ diffusion, their interaction causes important disagreements between experimental results and model calculations. DICTRA failed to simulate the diffusion annealing when the concentration profiles of the coating after hot dipping and the composition of the substrate were loaded as initial conditions. This is probably due to the lack of information in the database for alloys containing around $75 \% \mathrm{Al}$ and $25 \% \mathrm{Si}$. Nevertheless, when the concentration profile after 5 minutes of annealing is loaded as initial condition, further simulations were in general successful, as is illustrated in figure 9. The progress of silicon through the thickness is accurately reproduced, but not for the concentration in the area near the surface. The difference between the surface concentration measured experimentally and the concentration predicted by DICTRA may be due to silicon loss by evaporation or oxidation during annealing and subsequent de-scaling before measuring. More details concerning the modeling of the diffusion process can be found in ${ }^{[25]}$.

\subsection{Crystallographic texture}

As mentioned above, the magnetic properties of electrical steel are related to the microstructure and texture of the steel. Although the anisotropy of the magnetization behavior causes the crystallographic texture to be an important parameter for overall quality of the electrical steel, it is not yet possible to obtain optimal textures in commercially produced electrical steels. This is caused by the complexity of texture formation and the interaction with other microstructural characteristics, as mentioned above, despite the various efforts that are given in literature ${ }^{[26-31]}$ to optimize the texture of non-oriented electrical steel by varying thermo-mechanical processing. Therefore, in order to describe and quantify the magnetic texture quality of a non-oriented electrical

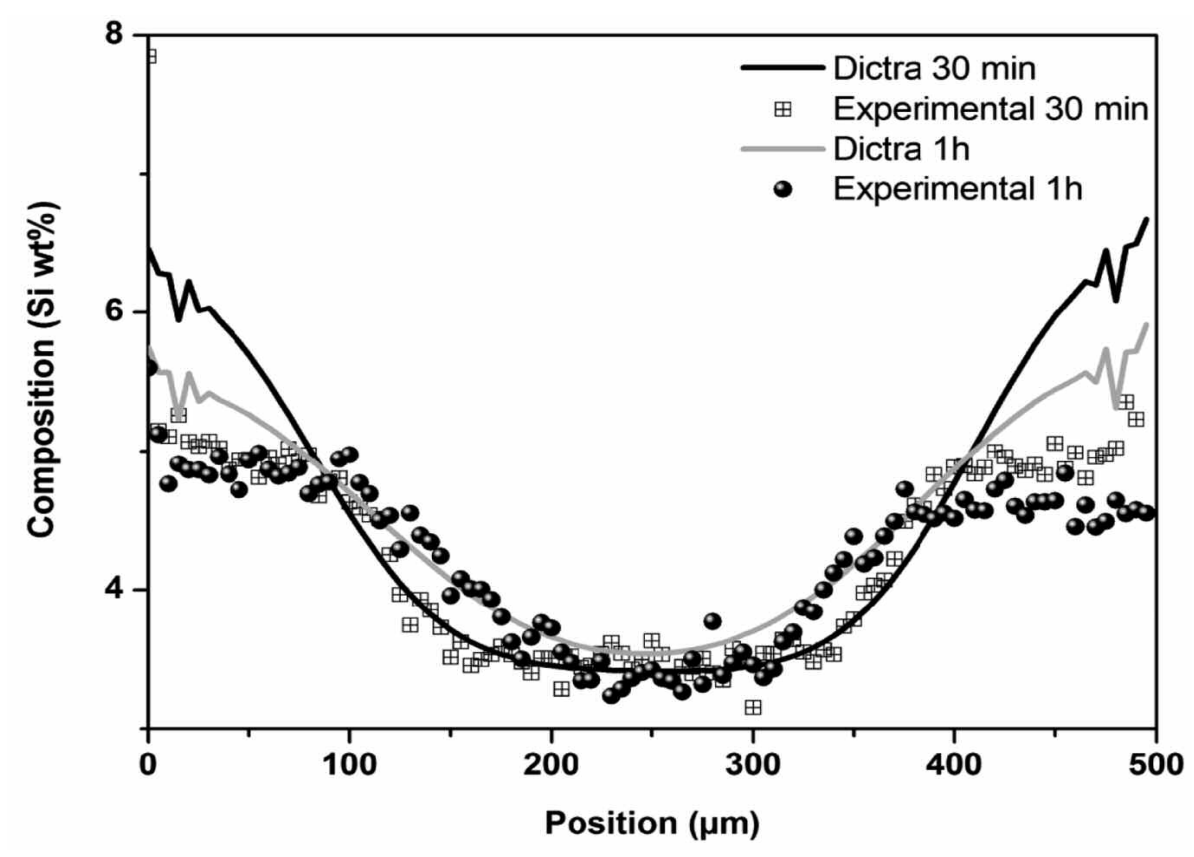

Figure 9. DICTRA ${ }^{\circledR}$ simulation of diffusion annealing for a substrate Fe 3 wt \% Si using as initial conditions the diffusion profile measured after $5 \mathrm{~min}$ of annealing at $1,100^{\circ} \mathrm{C}$.

Figura 9. Simulación en DICTRA del recocido de difusión para un material con Fe-Si $3 \%$ en peso, usando como condiciones iniciales el perfil de concentración medido después de un recocido durante 5 min a $1.100^{\circ} \mathrm{C}^{[8]}$. 
INNOVATIVE PROCESSING FOR IMPROVED ELECTRICAL STEEL PROPERTIES INNOVACIÓN DEL PROCESO PARA MEJORAR LAS PROPIEDADES DE LOS ACEROS ELÉCTRICOS

steel, two alternatives were suggested. A first one was defined by Kestens and Van Houtte ${ }^{[32]}$ and can be derived from the experimentally determined orientation distribution function (ODF), which is reflected in the function $f(g)$. The orientation $g$ is defined by its Euler angles. A schematic illustration is given in figure 10. For each ODF data point, the angle is determined which is the minimum angle of the three angles $\alpha_{1}, \alpha_{2}$ and $\alpha_{3}$ between one of the $<100>$ directions of easy magnetization of the crystal in the polycrystalline material and the direction of the macroscopic magnetization vector $\mathrm{M}$ in the material. The externally applied magnetic field, which is represented by this magnetization vector $\mathrm{M}$, makes an angle $\theta$ with respect to the rolling direction (RD) of the sheet. For the sake of simplicity $\theta$ is taken 0 in figure 10. The volume fraction of orientations in an infinitesimal environment of $\mathrm{g}$ is given by $\mathrm{f}(\mathrm{g}) \mathrm{dg}$. Finally, a texture parameter $A_{9}$ is defined in equation (1).

$$
A_{\vartheta}=\int f(g) A(g) d g
$$

Where $A_{\theta}$ is the texture parameter in the case that the magnetic field vector $M$ is applied in a direction making an angle $\theta$ with the rolling direction. The value of $A_{\theta}$ ranges from 0 to $54.7^{\circ}$. In a non-oriented electrical steel that is typically used in a rotating part of an electrical machine, the direction of $\mathrm{M}$ rotates with respect to the rolling direction of the material and an average A parameter is defined as determined by equation (2).

$$
A=\int A_{\vartheta} d \theta
$$

An alternative way to describe the magnetic quality of a non-oriented electrical steel might be the magnetic anisotropy energy $E_{a}$. In order to study whether both descriptions are equivalent, Gomes et al. ${ }^{[33]}$ calculated both $\mathrm{E}_{\mathrm{a}}$ and the A parameter for several $\mathrm{Fe}$-Si steels with variable silicon content. A perfectly linear relationship was found between both parameters, which demonstrated that both parameters can be used to describe the magnetic quality of the steel. Moreover, it was also shown elsewhere ${ }^{[33]}$ that the A-parameter, together with the grain size and a parameter related with the chemical composition of the steel could nicely predict the magnetic induction $\mathrm{B}$ at different values of the applied field $\mathrm{H}$, ranging from 500 to $5000 \mathrm{~A} / \mathrm{m}$.

As was discussed in more detail elsewhere ${ }^{[24]}$ the microstructure and texture for two samples; one with inhomogeneous and one with homogeneous $(\mathrm{Si}, \mathrm{Al})$ distribution after dipping and annealing were evaluated. Both samples contained about 4.8 wt \% $\mathrm{Si}$ after dipping and diffusion annealing, only the annealing time during diffusion was different. The

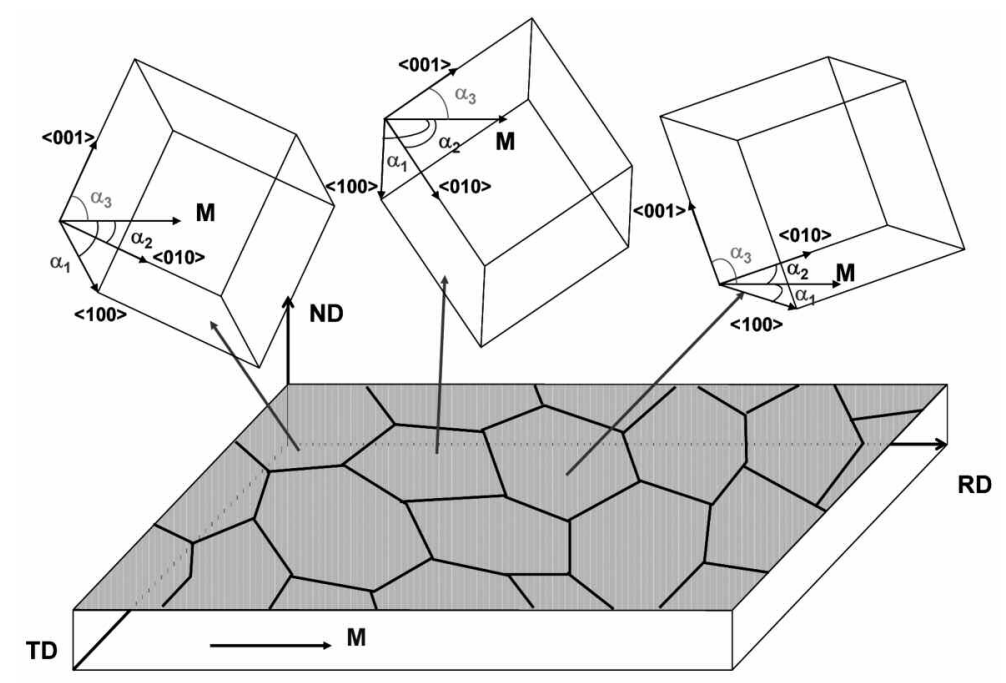

Figure 10. Schematic illustration on how the minimum angle between the magnetization vector $\mathrm{M}$ and closest easy magnetization $<100>$ direction is defined.

Figura 10. Representación esquemática de como es definido el mínimo ángulo entre el vector de magnetización $M$ y la dirección mas fácil de magnetizar $<100>$. 
high annealing temperature induced a considerable grain coarsening, i.e., $115 \mu \mathrm{m}$ for the inhomogeneous and about $260 \mu \mathrm{m}$ for the homogeneous sample were obtained. Texture analysis by X-ray diffraction showed some intensity on the cube fibre near the surface area for both samples, but all together texture intensities were quite similar for both samples and no effect of ( $\mathrm{Si}, \mathrm{Al}$ ) diffusion could be derived.

\section{CONCLUSIONS}

Using the described procedure, it is possible to produce steel sheet with an increased $\mathrm{Si}+\mathrm{Al}$ content. The interaction between $\mathrm{Fe}$-Si alloys and molten Al-25 wt \% Si and the phenomena during diffusion annealing have been studied. The growth of an ordered $\mathrm{Fe}_{3} \mathrm{Si}\left(\mathrm{DO}_{3}\right)$ layer with a strong dependence on the silicon content of the substrate is characteristic for the process. Magnetic properties still have to be optimized through an advanced control of texture and grain size.

\section{Acknowledgements}

This work has been supported by the EU through the projects SILSTEEL (Brite-EuRam III BRPR-CT980727: "Warm Working for High Silicon Electrical Steel") and DIFFANSTEEL (FP5 NNE5-2001-00600: "Production of Energy Saving High Silicon Electrical Steel by Hot dip coating and Diffusion Annealing"). Additional support was granted by Ghent University (BOF and GOA) and by the Belgian Government through IWT (STWW-980357) and FWO: projects G.0076.95N, G.00570, G.0228.96 and G.0420.99. Kim Verbeken works as a Postdoctoral Fellow of the Fund for Scientific Research - Flanders (Belgium) (F.W.O.-Vlaanderen).

\section{REFERENCES}

[1] C. Chen, Magnetism and Metallurgy of soft magnetic materials. North Holland, 1977.

[2] N.P. Goss, Trans. Am. Soc. Met. 23 (1935) 511.

[3] Patent DE 10220282, WO 03095683.

[4] K. Okada, T. Yamaji and K. Kasai, ISIJ International 36 (1996) 706-713.

[5] X.D. He, X. Li and Y. Sun, JMMM 320 (2008) 217-221.

[6] D. Dong, C. Liu, B. Zhang and J. Miao, J. Univ. Sci. Technol. B. 14 (2007) 321-325.

[7] T. Ros-Yanez, Y. Houbaert and V.Gomez, J.App.Phys. 91 (2002) 7.857-7.859.

[8] I. Infante Danzo, K. Verbeken and Y. Houbaert, Defect Diffus. Forum 297-301 (2010) 370-375.
[9] Patent DE 102005004037.

[10] J. Barros, T. Yanez, L. Vandenbossche, L. Dupre, J. Melkebeek and Y. Houbaert, J. Magn. Magn Mater. 290 (2005) 1457-1460.

[11] J. Barros, T. Yanez, M. De Wulf and Y. Houbaert, IEEE T. Magn. 40 (2004) 2739-2741.

[12] S. Gupta, Mater. Charact. 49 (2002) 269-291.

[13] T. Maitra and S. Gupta, Mater. Charact. 49 (2002) 293-311.

[14] M. Akdeniz and A. Mekhrabov, Acta Mater. 46 (1998) 1.185-1.192.

[15] J. Nichols, Corros. Technol. 16 (1964) S17-S28.

[16] T. Heumann and S. Dittrich, Z. Metallkd. 50 (1959) 617-625.

[17] N. Komatsu, M. Nakamura and H. Fujita, J. Jpn. I. Met. 45 (1981) 416.

[18] G. Eggeler, W. Auer and H. Kaesche, J. Mater. Sci. 21 (1986) 3.348-3.350.

[19] N. Baldwin and D. Ivey, J. Phase Equilib. 16 (1995) 300-307.

[20] D. Pierre, F. Barbeau, M. Peronnet, F. Bosselet, J. C. Viala and J. Bouix, Mater. Sci. Eng B 94 (2002) 186-195.

[21] K. Murakami, N. Nishida, K. Osamura, Y. Tomota and T. Suzuki, Acta Mater. 52 (2004) 2.173-2.184.

[22] V. Dybkov, J. Mater. Sci. 25 (1990) 3.615-3.633.

[23] J. Barros, Ph.-D.-thesis, Faculty of Engineering, Ghent University, 2006.

[24] J. Verstraete, K. Verbeken, J. Schneider and Y. Houbaert, IEEE T. Magn. 44 (2008) 3.8243.827.

[25] J. Barros, B. Malengier, R. Van keer and Y. Houbaert, J. Phase Equilib. Diffus. 26 (2005) 417 422.

[26] H. Huneus, K. Gunther, T. Kochmann, V. Plutniok and A. Schoppa, J. Mater. Eng. Perform. 2 (1993) 199.

[27] M. Kohno, M. Muraki, M. Kawano and M. Komatsubara, Mater. Sci. Forum 408-412 (2002) 785.

[28] J.T. Park, J.A. Szpunar and S.Y. Cha, ISIJ Int. 43 (2003) 1611.

[29] K. Verbeken, J. Schneider, J. Verstraete, H. Hermann and Y. Houbaert, IEEE T. Magn. 44 (2008) 3.820-3.823.

[30] E. Gomes, J. Schneider, K. Verbeken, H. Hermann and Y. Houbaert: Materials Science Forum 638-642 (2010) 3.561-3.566.

[31] K. Verbeken, E. Gomes, J. Schneider and Y. Houbaert, Solid State Phenomena 160 (2010) 189-194.

[32] L. Kestens, Ph.-D.-thesis, Faculty of Engineering, Catholic University Leuven, Belgium, 1994.

[33] E. Gomes, J. Schneider, K. Verbeken, J. Barros and Y. Houbaert, IEEE T. Magn. 46 (2010) 310-313. 